\title{
Ti-mineral stability in metagabbros formed at different stages of the Wilson cycle
}

\author{
INÊS PEREIRA ${ }^{1}$, EMILIE BRUAND ${ }^{2}$, KENNETH T. KOGA ${ }^{3}$ \\ AND CHRISTIAN NICOLLET ${ }^{3}$ \\ ${ }^{1}$ Universite Clermont Auvergne \\ ${ }^{2}$ Laboratoire Magmas et Volcans \\ ${ }^{3}$ Université Clermont Auvergne \\ Presenting Author: emilie.bruand@uca.fr
}

Rutile, titanite and ilmenite are the most common Ti-bearing minerals in metamorphic rocks at variable grades. Titanite is more stable at low-grade metamorphic conditions, rutile at HP (> 12 kbar), while ilmenite at HT-LP conditions. However, recent work by Angiboust and Harlov (2017) on granitoid compositions suggested that $\mathrm{CaO}$ could markedly increase the stability of titanite towards HP, in agreement with petrological observations of titanite at $20 \mathrm{kbar}$ and $390^{\circ} \mathrm{C}$. This highlights that further constraints are needed to better understand Ti-phase stability at different P-T-X conditions.

In this study, we have investigated the natural occurrence of Ti-bearing minerals in gabbroic rocks that record different stages of metamorphism during a Wilson cycle. These comprise metagabbros from the IODP, from an obducted ophiolite (Chenaillet) and alpine HP units that include blueschist (Schistes Lustrés) and eclogite (Monviso) rocks from the western Alps. We have performed detailed petrography, using SEM, and analysed major and trace elements (TE) mineral chemistry using EPMA and LA-HR-ICPMS.

In the IODP and Chenaillet metagabbros, a clear transition from brown to green amphibole is observed, replacing former clinopyroxene. Ilmenite is unstable and systematically overgrown by titanite, found at the boundary between brown and green amphiboles, indicating it stabilised at lower temperatures. Rutile is also found in these ilmenite-titanite domains, either as coarser grains inside ilmenite, or as finer grains within titanite overgrowths. These rutile formed during HT-LP metamorphism during gabbro emplacement in the ocean floor. Interestingly, these HT textures can be tracked to rocks that have undergone LT-HP metamorphism, such as in the Schistes Lustrés rocks. In these, titanite is clearly stable with the blueschist assemblage, but small remnants of rutile are often observable within titanite. TE compositions from these rutile grains are similar to those from the ocean-floor $(\mathrm{Sc})$, and thus are remnants from ocean floor processes. As the slab is buried to increased depths, titanite breaks down to form new rutile at eclogite facies conditions, with distinct TE compositions.

Finally, in this study, we reveal that trace element compositions of titanite and rutile at different P-T show some chemical systematics that are potentially P-T sensitive. 